\title{
Comparative size-specific grazing rates in field populations of ciliates and dinoflagellates
}

\author{
Susanne Neuer *, Timothy J. Cowles \\ College of Oceanic and Atmospheric Sciences, Oregon State University, Corvallis, Oregon 97331, USA
}

\begin{abstract}
We compared specific feeding rates of ciliates and thecate and gymnodinoid dinoflagellates on the natural food spectrum applying a dual-label isotope method (Daro 1978, Helgoländer wiss Meeresunters 31:241-248; Lessard \& Swift 1985, Mar Biol 87:289-296) in coastal waters off Oregon, USA. Ciliates had the highest size-specific clearance rates on heterotrophic food sources with an average of $3.9 \times 10^{5}$ body volumes (BV) $\mathrm{h}^{-1}$. Gymnodinoid dinoflagellates strongly selected for phototrophic food sources and showed the highest size-specific clearance rates on phototrophs with an average of $2.2 \times 10^{5} \mathrm{BV} \mathrm{h}^{-1}$ The range of clearance rates on photosynthetic organisms in gymnodinoids overlapped with that in the ciliates. We also present evidence for bacterivory in gymnodinoid dinoflagellates with a mean of $2.4 \times 10^{4} \mathrm{BV} \mathrm{h}^{-1}$, comparable to bacterivory by thecate dinoflagellates, but more than an order of magnitude lower than the mean found for the ciliates studied. Our data indicate that in gymnodinoid dinoflagellates, small cells have higher size-specific clearance rates than larger cells. The composition as well as the size distribution of the grazer populations need to be considered when comparing the grazıng impact of ciliates and dinoflagellates on prey populations in the field.
\end{abstract}

KEY WORDS: Phagotrophic protists - Ciliates · Dinoflagellates · Grazing

\section{INTRODUCTION}

Heterotrophic ciliates (mostly choreotrich forms) and dinoflagellates are the 2 major groups of marine phagotrophic protists in the microplankton size range (20 to $200 \mu \mathrm{m}$ ). Ciliates are an important constituent of microbial food webs and provide a link to higher trophic levels (e.g. Heinbokel 1978, Rassoulzadegan 1982, Verity 1985, 1991, Jonsson 1986, Sherr \& Sherr 1987, Stoecker \& Capuzzo 1990). In more recent studies, heterotrophic dinoflagellates were also found to be important grazers in marine ecosystems, especially of phytoplankton (Lessard \& Swift 1985, Jacobson \& Anderson 1986, Bjørnsen \& Kuparinen 1991, Hansen 1991, 1992, Lessard 1991, Strom 1991, Nakamura et al. 1992, Strom \& Buskey 1993, Jeong \& Latz 1994). However, a comparative study of the ecological importance of both protist groups is still lacking.

\footnotetext{
- Present address: Dept of Geosciences, FB 5, University of Bremen, Klagenfurter Straße, D-28359 Bremen, Germany; E-mail: susanne@zfn.uni-bremen.de
}

The prey size spectrum of ciliates and dinoflagellates is similar (Lessard \& Swift 1986, Hansen 1991, Strom 1991). However, dinoflagellates larger than $20 \mu \mathrm{m}$ in length can graze prey of equal or larger size than themselves (e.g. Jacobson 1986, Hansen 1992), thus exceeding the prey size range of choreotrich ciliates (e.g. Fenchel 1986). This has been interpreted as an evolutionary advantage of dinoflagellates over ciliates, especially during bloom situations with large phytoplankton (Lessard 1991, Hansen 1992). Another factor relevant to understanding the feeding ecology of ciliates and dinoflagellates is their intrinsic growth potential. Under optimal laboratory conditions, ciliates grow 2 to 3 times faster than dinoflagellates of the same body volume (Banse 1982, Hansen 1992). This difference in growth rates implies that differences in either feeding rates or growth efficiency, or both, must exist between these 2 groups. Feeding rates and growth efficiency determine the grazing impact on prey populations and the regeneration efficiency of nutrients, and hence establish the functional role of these grazers in the ecosystem. Hansen (1992) found evidence that 
the growth efficiency of dinoflagellates might be lower than that of other phagotrophic protists, including ciliates.

In this study we investigated how specific clearance rates of the 2 groups compare in the field. Using a cellspecific grazing assay, the dual-label isotope technique (Daro 1978, Lessard \& Swift 1985), we were able to compare size-specific feeding rates of field populations of ciliates and dinoflagellates grazing on the natural food spectrum. We found that the ability to ingest phototrophic food compared well among ciliates and dinoflagellates, but that size-specific bacterivory was higher in ciliates.

\section{METHODS}

Experimental setup. A total of 19 grazing experiments using the dual-label isotope method were performed in the upwelling system off Oregon, USA, during 1990 and 1991 . The 2 isotopes were ${ }^{14} \mathrm{C}$-bicarbonate and ${ }^{3} \mathrm{H}$-thymidine, labelling phototrophic and heterotrophic (mainly heterotrophic bacteria) food sources, respectively. Water was collected using 51 Niskin bottles at bimonthly to monthly intervals in 1990 and 1991 from 7 to $9 \mathrm{~m}$ depth in nearshore waters west of Newport. The collected water was immediately transferred to acid-washed polycarbonate carboys that were cooled with running surface seawater and shaded during transit to the laboratory. The carboys then were stored at $10^{\circ} \mathrm{C}$ (approximate in situ temperature; Neuer 1992). The experimental procedures follow those outlined in Lessard \& Swift (1985). About $7 \mathrm{~h}$ after collection, water from the carboys was incubated in three or four $250 \mathrm{ml}$ acid-cleaned polycarbonate bottles with $1 \mu \mathrm{Ci} \mathrm{ml}^{-1}$ of tritiated thymidine (hereafter ${ }^{3} \mathrm{H}_{i}$ specific activity $68 \mathrm{Ci} \mathrm{mmol}{ }^{-1}$ ) and ${ }^{14} \mathrm{C}$-bicarbonate (hereafter ${ }^{14} \mathrm{C}_{i}$ specific activity $56 \mathrm{mCi} \mathrm{mmol}^{-1}$ ) (both isotopes were obtained from ICN Chemical and Radioisotope, Irvine, CA, USA). In some experiments carried out in 1990, 1 to 31 of water from the carboys was first collected over a submerged $20 \mu \mathrm{m}$ Nitex mesh to concentrate the particulate fraction $>20 \mu \mathrm{m}$, mixed with unscreened water from the carboys and then filled into the bottles. The bottles were incubated at $10^{\circ} \mathrm{C}$ for 1 to $3 \mathrm{~h}$ at $100 \mu \mathrm{mol}$ photons $\mathrm{m}^{-2} \mathrm{~s}^{-1}$ (photosynthetically available radiation, PAR) from fluorescent light tubes.

Determination of radiolabel uptake in the particulate fraction. At the end of the incubation, replicate aliquots were filtered from each flask onto $0.2 \mu \mathrm{m}$ polycarbonate filters (Poretics) to determine the radiolabel taken up by the total particulate fraction. A second set of replicate aliquots was prefiltered through a $20 \mu \mathrm{m}$ Nitex mesh, prior to filtration onto $0.2 \mu \mathrm{m}$ filters, to determine the activity of the fraction smaller than
$20 \mu \mathrm{m}$. Because only 1 flask could be processed at a time, flasks were maintained at $4^{\circ} \mathrm{C}$ in the dark from the end of incubation until filtration to minimize continued uptake and transfer of label by the organisms inside the flasks. The filters, including the rim, were carefully rinsed 3 times with $0.2 \mu \mathrm{m}$ filtered water collected from the same site to remove all isotope not fixed in the particulate fraction, and placed into $20 \mathrm{ml}$ scintillation vials. The efficiency of this washing procedure was tested by determining the activity of filters containing cells from pasteurized $\left(70^{\circ} \mathrm{C}, 20 \mathrm{~min}\right)$ flasks. The heat-killed cells contained less than $1 \%$ of isotope compared to filters containing live cells (see below), evidence for the efficient removal of the dissolved isotope from the filters.

Determination of radiolabel in the grazers. The remaining water in each flask was filtered through a submerged beaker that had a 10 or $20 \mu \mathrm{m}$ Nitex mesh as bottom to concentrate the particulate fraction containing the grazers. The beaker with the cells was transferred 3 times into unlabeled water to remove label not contained in cells. The organisms retained on the filters were kept suspended in filtered seawater and refrigerated at $4^{\circ} \mathrm{C}$ until isolation (less than $1 \mathrm{~h}$ after filtration). Heterotrophic ciliates and dinoflagellates were isolated quickly with drawn-out micropipettes under a dissecting microscope and then transferred through 3 rinses of filtered seawater (to wash off any remaining label). Before the cells were pipetted into $20 \mathrm{ml}$ scintillation vials, their dimensions were measured using a Zeiss Videoplan Image Analysis System attached to the dissecting scope. Mixotrophic species could be distinguished by their photopigments and were not considered, since the dual-label isotope method cannot distinguish between grazing of labelled phototrophic cells and photosynthesis by retained chloroplasts. Cells belonging to one taxonomic group (see below) and size class were micropipetted into scintillation vials. If cell abundance was sufficient, replicate vials of an organism group were taken. Only data from vials containing 2 to 5 cells were considered for further analysis in order to include intercellular variability. In the results reported below each vial constitutes a data point. The vials also contained $1 \mathrm{ml}$ of $0.2 \mathrm{~N}$ perchloric acid to digest the cells and to drive off the ${ }^{14} \mathrm{C}$-label as ${ }^{14} \mathrm{CO}_{2}$. Ecolume (ICN) scintillation cocktail ( 4 or $8 \mathrm{ml}$ ) was added to all scintillation vials.

Determinations of sample DPMs. Samples were counted in replicate using a Packard Tri-Carb Liquid Scintillation Analyzer model $1900 \mathrm{CA}$ in the highsensitivity dual-label count mode. The instrument converted counts to disintegrations per minute (DPM) applying a quench indication parameter programmed from a quench curve. Mean background counts were 
obtained from measurements of several replicate vials containing scintillation cocktail and $0.1 \mathrm{ml}$ of filtered seawater from the last rinse water used for the protists. This last rinse water did not contain any radioactivity above background level. Final sample DPMs were obtained by subtracting the mean background DPM from the raw sample DPMs. The maximum $2 \sigma$ range determined for the lowest background samples (range 10 to 14 DPM) was between 10 and $13 \%$.

The effective separation of the ${ }^{3} \mathrm{H}$ and ${ }^{14} \mathrm{C}$ courting regions by the liquid scintillation counter is critical when counting low-activity samples because of the overlap in electron energy spectra of the 2 isotopes. By running a series of low-count standards of either ${ }^{3} \mathrm{H}$ or ${ }^{14} \mathrm{C}$ we determined that, for the low counts obtained for the single cell vials (less than 200 DPM), the separation of the counting ranges was effective and that no spill-over of the ${ }^{14} \mathrm{C}$ electron emission region into the ${ }^{3} \mathrm{H}$ emission region occurred.

Taxonomic grouping and size determinations. The dinoflagellates were grouped into gymnodinoid and thecate forms. Gymnodinoid forms belonged to the order Gymnodiniales and thecate dinoflagellates were represented by the abundant genus Protoperidinium and cells of genera belonging to the Diplopsalis group (Dodge 1982, Never 1992). Among the heterotrophic ciliates, choreotrichs and cells of the genus Tiarina (Colepidae; Corliss 1979) were abundant (Neuer 1992). Tintinnids were classified to genus (mainly after Wailes 1939). We calculated biovolume of the isolated grazer cells by converting the linear dimensions determined with the image analysis system to geometric shapes as recommended in Edler (1979).

Rate calculations. The partitioning and transfer of label between water, prey and grazer during the incubation time is conceptualized by a 3 compartment model (Daro 1978):

Water $\left(q_{1}\right) \stackrel{\lambda_{1}}{\longrightarrow}$ Prey $\left(q_{2}\right) \stackrel{\lambda_{2}}{\longrightarrow}$ Grazer $\left(q_{3}\right) \stackrel{\lambda_{3}}{\longrightarrow}$

in which $q$ is the activity of label in a compartment and $\lambda$ the transfer rate between 2 compartments. The transfer between the compartments is modelled by differential equations and, assuming that $q_{1} \gg q_{2}$ and that $\lambda_{3}$. the rate of isotope recycling, is negligible (see below), grazing rate $\lambda_{2}$ is given by

$$
\lambda_{2}=2 q_{3} /\left(q_{2} t\right)
$$

where $q_{2}$ is the isotope incorporated in the prey compartment, $q_{3}$ is the label in the grazer compartment, and $t$ is time. The units of both compartments are DPM $\mathrm{I}^{-1}$ and, consequently, the unit of $\lambda_{2}$ is time ${ }^{-1}$. In order to calculate a cell-specific grazing rate, we modify Eq. (1) by dividing both sides of the equation by the abundance of cells, $A$ (cells ${ }^{-1}$ ), so that

$$
\lambda_{2} / A=2 q_{3} /\left(A q_{2} t\right)
$$

By making $\lambda_{2}{ }^{*}=\lambda_{2} / A$, and $q_{3}{ }^{*}=q_{3} / A$, we obtain

$$
\lambda_{2} \cdot=2 q_{3} \cdot /\left(q_{2} t\right)
$$

where $\lambda_{2}{ }^{*}$ is the specific grazing rate with units of 1 cell $^{-1}$ time ${ }^{-1}$, and $q_{3}{ }^{\cdot}$ the label incorporated into each grazer cell with units of DPM cell ${ }^{-1}$. Consequently, we can calculate the specific grazing rate $\lambda_{2}$ ' by measuring the label incorporated into each grazer cell or group of cells, and by determining $q_{2}$, the label incorporated into the prey compartment, and can thus express grazing rate as specific clearance rate with units of volume cleared per grazer cell and unit of time.

The conceptual background for applying Daro's model to the dual-label isotope technique is based on the assumption that ${ }^{14} \mathrm{C}$ is taken up by phototrophic prey (autotrophic algae) and ${ }^{3} \mathrm{H}$ by heterotrophic prey (bacteria and/or other bacteriovores; Lessard \& Swift 1985). During the incubation time of up to $3 \mathrm{~h}$, most of the ${ }^{3} \mathrm{H}$ will be in the bacteria pool, however. Assuming an average abundance of bacteria and heterotrophic flagellates of $10^{6}$ and $10^{3}$ cells $\mathrm{ml}^{-1}$, respectively, and an average clearance rate on bacteria of $1 \mathrm{nl} \mathrm{h}^{-1}$ (E. Sherr \& J. Gonzalez pers. comm.), only about $0.3 \%$ of the bacteria would be ingested by bacterivorous flagellates during the incubation period. Thus, when talking about ingestion of ${ }^{3} \mathrm{H}$-labelled food sources, we will be using the expressions 'uptake of heterotrophic food sources' and 'bacterivory' interchangeably. To quantify the grazing impact (clearance rate) on a certain food source it is crucial to accurately determine the size range of the possible food source, i.e. which fraction of the labelled particulate matter to use as $q_{2}$ in the denominator of Eq. (1"). For example, using Lessard \& Swift's (1985) approach, the particulate fraction smaller than $20 \mu \mathrm{m}$ was considered available prey to grazers larger than $20 \mu \mathrm{m}$. This predator-prey size relationship is reasonable for suspension feeders such as choreotrich ciliates, but not for thecate dinoflagellates which feed with a pallium (an extension of their protoplast) and ingest a wide size range of prey organisms (Gaines \& Taylor 1984, Jacobson \& Anderson 1986). Also, gymnodinoid dinoflagellates larger than $20 \mu \mathrm{m}$ are able to engulf prey larger than $20 \mu \mathrm{m}$ (Neuer 1992, Jacobson \& Anderson 1986, Hansen 1992). Therefore, for thecate dinoflagellates, gymnodinoids larger than $20 \mu \mathrm{m}$ and Tiarina, $q_{2}$ was defined as the activity in the total particulate fraction while the labelled particulate from the $<20 \mu \mathrm{m}$ fraction was considered the available prey for choreotrichs and smaller gymnodinoids $(\leq 20 \mu \mathrm{m})$.

Several assumptions are implicit in Daro's (1978) model. It is assumed that regeneration or excretion of label during the incubation period is negligible. The 
assumption of negligible isotope recycling and excretion is supported by the observation that ingestion rate is linear within the first $3 \mathrm{~h}$ of incubation (Lessard \& Swift 1985, Sherr et al. 1988, Hansen 1992, Neuer unpubl.). In addition, the model assumes that no label is taken up osmotically by the grazers or adsorbed to the surface of the cells. Lessard \& Swift (1985) determined that direct uptake of thymidine was not a substantial part of the total uptake in heterotrophic dinoflagellates and that the measured uptake of label reflected feeding on particulates. We found less than $1 \%$ adsorption of label to the particulate fraction following incubation of heat-killed water samples. No significant radioactivity was detected in isolated heatkilled cells (Lessard \& Swift 1985).

Theoretically, clearance rates are constant within the range of food concentrations in which ingestion rates are linear with food concentration (see Frost 1972). In such a case, clearance rates can be compared among different individuals. In dilution experiments (Landry \& Hassett 1982) conducted on the same dates, we found no evidence for non-linear feeding kinetics (Neuer \& Cowles 1994). This implies that measured clearance rates on phototrophic food particles can be compared. However, we do not have data on feeding kinetics involving bacteria. The high specific clearance rates $\left[>10^{6}\right.$ body volumes (BV) $h^{-1}$; see Table 1$]$ for ciliates (Stenosemella) feeding on ${ }^{3} \mathrm{H}$-labelled particulates were obtained on dates when bacterial biomass was low. This suggests that a threshold feeding response at low bacterial abundance might have occurred then. Microscopic investigation of the tintinnids using epifluorescence microscopy on DAPI stained samples did not reveal that bacteria were attached to the walls of the loricae.

Size-specific clearance rates (in fractions of $\mathrm{BV} \mathrm{h}^{-1}$ ) were obtained by normalizing clearance rates by the biovolume of the grazer, thus expressing clearance rates in units of BV cleared per unit of time. Sizespecific clearance rates were used to compare feeding performances between ciliates and dinoflagellates while accounting for differences in size, and within a group to investigate the presence of a relationship with the size of the grazer. To determine size-clearance rate relationships, the logarithm of the specific clearance rates was regressed linearly with biovolume, applying the linear regression model with replicated design (Sokal \& Rohlf 1981). In those protist groups where a size relationship was found, this allowed for the best correlation.

We calculated a food selectivity index for each vial to compare differential utilization of the natural food spectrum between and among ciliates and dinoflagellates. Selectivity was determined by dividing the clearance rate on ${ }^{3} \mathrm{H}$-labelled particulate matter by total clearance (sum of clearance on ${ }^{3} \mathrm{H}$ - and ${ }^{14} \mathrm{C}$-labelled particulates). Thus, a selectivity index close to 1 indicates a diet based on heterotrophic food sources, and a selectivity close to 0 points to a selection of phototrophic food sources in the diet.

\section{RESULTS}

Table 1 presents all the data obtained on clearance rates and size-specific clearance rates for the 3 groups of phagotrophic protists investigated. Also presented are cell length and cell volume, which were used to calculate size-specific clearance rates. Background DPMs are also shown to enable comparisons with sample DPMs. At times, sample vials had activities close to or at background, in which cases the calculated clearance rate was zero.

Due to the washing procedure with the Nitex mesh which was used to remove the soluble radiolabel from the cells (see 'Methods'), most non-loricate ciliates were lost. Thus, the available ciliate cell abundance was so low that only rarely could more than 1 cell per vial be isolated. Vials containing only 1 cell were not considered for data analysis. The most abundant type isolated was cells of the tintinnid genus Stenosemella. Stenosemella and Helicostomella displayed the highest clearance rates on heterotrophic particulate matter $\left({ }^{3} \mathrm{H}\right.$-based rates) of all protist groups (Table 1). Thecate and gymnodinoid dinoflagellates had much lower rates of bacterivory. Gymnodinoids, on the other hand, had the highest clearance rates on phototrophic material, with ciliates and thecate dinoflagellates exhibiting lower rates (Table 1 ).

The mean size-specific clearance rates (clearance rates normalized to biovolume), separated into grazing on heterotrophic and phototrophic food sources, are shown with their $95 \%$ confidence intervals (CI) in Fig. 1. Ciliates had the highest size-specific clearance on heterotrophic food, with a mean of $3.9 \times 10^{5} \mathrm{BV} \mathrm{h}^{-1}$. and the $95 \% \mathrm{CI}\left(1.6 \times 10^{5}\right.$ to $\left.9.5 \times 10^{5} \mathrm{BV} \mathrm{h}^{-1}\right)$ did not overlap with those of the other 2 groups. Thecate and gymnodinoid dinoflagellates, consuming about an order of magnitude less ${ }^{3} \mathrm{H}$-labelled food than the ciliates, had identical mean specific clearance rates of $2.4 \times 10^{4} \mathrm{BV} \mathrm{h}^{-1}$. The $95 \% \mathrm{CI}$ was narrower for the thecates $\left(1.1 \times 10^{4}\right.$ to $\left.5.1 \times 10^{4} \mathrm{BV} \mathrm{h}^{-1}\right)$ than for the gymnodinoid dinoflagellates $\left(0.5 \times 10^{4}\right.$ to $1.2 \times 10^{5} \mathrm{BV}$ $\mathrm{h}^{-1}$ ). However, gymnodinoid dinoflagellates clearly exhibited the highest mean specific clearance rates on phototrophic food sources $\left(2.2 \times 10^{5} \mathrm{BV} \mathrm{h}^{-1}\right)$, twice as high as the ciliates $\left(1.1 \times 10^{5} \mathrm{BV} \mathrm{h}^{-1}\right)$ and almost 4 times higher than the thecate dinoflagellates $\left(6.0 \times 10^{4} \mathrm{BV}\right.$ $\left.\mathrm{h}^{-1}\right)$. The $95 \% \mathrm{CI}$ of ciliate size-specific herbivory $(4.3 \times$ $10^{4}$ to $3.6 \times 10^{5} \mathrm{BV} \mathrm{h}^{-1}$ ) overlapped with those of the 
Table 1 Data summary of feeding experiments. Background $(B \mathrm{~kg})$ DPM is mean of 3 to 6 replicates of samples of the last rinse water. nd: because of zero clearance rate these data could not be log transformed

\begin{tabular}{|c|c|c|c|c|c|c|c|c|c|c|c|}
\hline \multirow{2}{*}{$\begin{array}{l}\text { Group } \\
\text { Ciliates }\end{array}$} & \multirow[t]{2}{*}{$\begin{array}{l}\text { Mean } \\
\text { cell length } \\
\{(\mu \mathrm{m})\end{array}$} & \multirow[t]{2}{*}{$\begin{array}{c}\text { Biovolume } \\
\left(10^{4} \mathrm{\mu m}^{3}\right)\end{array}$} & \multirow[t]{2}{*}{$\begin{array}{l}\text { Cells } \\
\text { vial }^{-1}\end{array}$} & \multicolumn{2}{|c|}{$\begin{array}{l}\text { DPM vial }{ }^{-1} \\
{ }^{3} \mathrm{H} \quad{ }^{14} \mathrm{C}\end{array}$} & \multicolumn{2}{|c|}{$\begin{array}{l}\text { Bkg DPMI } \\
{ }^{3} \mathrm{H}{ }^{1:} \mathrm{C}\end{array}$} & \multicolumn{2}{|c|}{$\begin{array}{l}\text { Clearance } \\
\text { rate } \\
{ }^{3} \mathrm{H} \quad{ }^{14} \mathrm{C}\end{array}$} & \multicolumn{2}{|c|}{$\begin{array}{c}\text { Log [specific } \\
\text { clearance }\left(\mathrm{BV} \mathrm{h}^{-1}\right) \\
{ }^{3} \mathrm{H}\end{array}$} \\
\hline & & & & & & & & & & & \\
\hline \multirow{12}{*}{ cf. Stenosemella } & 100 & 4.7 & 2 & 68 & 31 & 14 & 12 & 21.5 & 6.7 & 5.7 & 5.2 \\
\hline & 100 & 4.7 & 2 & 97 & 27 & 12 & 12 & 21.0 & 7.3 & 5.6 & 5.3 \\
\hline & 100 & 4.7 & 2 & 83 & 18 & 12 & 12 & 17.3 & 2.8 & 5.6 & 4.8 \\
\hline & 100 & 4.7 & 3 & 117 & 19 & 12 & 12 & 17.4 & 2.2 & 5.6 & 4.7 \\
\hline & 100 & 4.7 & 3 & 151 & 13 & 12 & 12 & 23.2 & 0 & 5.7 & nd \\
\hline & 110 & 5.2 & 2 & 57 & 16 & 17 & 12 & 73.7 & 6.1 & 6.1 & 5.1 \\
\hline & 60 & 1.4 & 2 & 47 & 30 & 17 & 13 & 8.4 & 5.2 & 5.8 & 5.6 \\
\hline & 70 & 2.1 & 3 & 106 & 21 & 17 & 13 & 16.8 & 1.7 & 5.9 & 4.9 \\
\hline & 70 & 2.2 & 2 & 113 & 16 & 17 & 13 & 27.1 & 1.6 & 6.1 & 4.9 \\
\hline & 70 & 2.2 & 4 & 249 & 40 & 17 & 13 & 59.9 & 7.2 & 6.4 & 5.5 \\
\hline & 70 & 2.2 & 3 & 176 & 24 & 17 & 13 & 54.8 & 3.8 & 6.4 & 5.2 \\
\hline & 70 & 2.2 & 4 & 280 & 30 & 17 & 13 & 67.7 & 4.6 & 6.5 & 5.3 \\
\hline \multirow[t]{2}{*}{ cf. Helicostomella } & 80 & 0.7 & 3 & 45 & 19 & 18 & 13 & 0.6 & 0.4 & 4.9 & 4.8 \\
\hline & 80 & 0.7 & 2 & 41 & 15 & 18 & 13 & 0.8 & 0.3 & 5.1 & 4.6 \\
\hline Non-loricate choreotrich & ch 60 & 3.0 & 2 & 17 & 20 & 17 & 13 & 0 & 2.2 & nd & 4.9 \\
\hline \multirow[t]{2}{*}{ Tiarina } & 80 & 3.2 & 3 & 54 & 15 & 22 & 12 & 0.5 & 1.8 & 4.2 & 4.7 \\
\hline & 80 & 3.2 & 3 & 41 & 23 & 22 & 12 & 0.3 & 5.9 & 4.0 & 5.3 \\
\hline \multicolumn{12}{|l|}{ Dinoflagellates } \\
\hline Gymnodinoids & 85 & 2.7 & 2 & 19 & 13 & 17 & 11 & 0 & 0 & nd & nd \\
\hline & 85 & 2.7 & 3 & 497 & 65 & 17 & 11 & 3.4 & 13.3 & 5.1 & 5.7 \\
\hline & 95 & 5.2 & 2 & 122 & 53 & 17 & 11 & 1.1 & 15.4 & 4.3 & 5.5 \\
\hline & 80 & 3.4 & 2 & 67 & 64 & 15 & 12 & 12.5 & 22.4 & 5.6 & 5.8 \\
\hline & 20 & 0.4 & 2 & 24 & 16 & 15 & 12 & 1.2 & 5.8 & 5.5 & 6.1 \\
\hline & 120 & 7.9 & 2 & 15 & 14 & 15 & 11 & 0 & 4.2 & nd & 4.7 \\
\hline & 120 & 7.9 & 3 & 19 & 67 & 15 & 11 & 0.5 & 54.1 & 3.8 & 5.8 \\
\hline & 120 & 7.9 & 5 & 15 & 54 & 15 & 11 & 0 & 5.1 & nd & 4.8 \\
\hline & 120 & 7.9 & 4 & 109 & 106 & 15 & 11 & 2.2 & 14.2 & 4.4 & 5.3 \\
\hline & 120 & 7.9 & 2 & 16 & 19 & 15 & 11 & 0 & 2.2 & nd & 4.4 \\
\hline & 120 & 7.9 & 2 & 19 & 167 & 15 & 11 & 0.1 & 21.6 & 3.1 & 5.4 \\
\hline & 120 & 7.9 & 3 & 19 & 48 & 15 & 11 & 0.1 & 3.4 & 3.1 & 4.6 \\
\hline & 90 & 3.0 & 2 & 19 & 55 & 15 & 11 & 1.1 & 18.7 & 4.6 & 5.8 \\
\hline & 70 & 2.0 & 2 & 20 & 14 & 18 & 13 & 0 & 0 & nd & nd \\
\hline Thecate dinoflagellates & $5 \quad 25$ & 0.7 & 3 & 16 & 18 & 12 & 12 & 0.5 & 0.6 & 4.9 & 4.9 \\
\hline & 100 & 13.1 & 3 & 823 & 29 & 12 & 12 & 78.9 & 1.7 & 5.8 & 4.1 \\
\hline & 40 & 2.5 & 4 & 16 & 22 & 12 & 12 & 0.3 & 0.8 & 4.1 & 4.5 \\
\hline & 100 & 11.3 & 3 & 25 & 43 & 14 & 12 & 1.3 & 0.7 & 4.1 & 3.8 \\
\hline & 30 & 4.7 & 2 & 25 & 62 & 14 & 12 & 2.0 & 1.6 & 4.6 & 4.5 \\
\hline & 40 & 2.5 & 2 & 19 & 29 & 12 & 13 & 0.6 & 1.6 & 4.4 & 4.8 \\
\hline & 100 & 11.8 & 2 & 150 & 94 & 17 & 11 & 4.2 & 5.1 & 4.6 & 4.6 \\
\hline & 100 & 11.8 & 3 & 214 & 223 & 17 & 11 & 4.2 & 8.7 & 4.6 & 4.9 \\
\hline & 100 & 11.8 & 2 & 17 & 21 & 17 & 11 & 0 & 0.6 & nd & 3.7 \\
\hline & 20 & 0.8 & 2 & 25 & 12 & 17 & 11 & 0.3 & 0 & 4.6 & nd \\
\hline & 30 & 1.9 & 2 & 24 & 26 & 17 & 11 & 0.2 & 0.9 & 4.0 & 4.7 \\
\hline & 90 & 6.9 & 3 & 49 & 46 & 22 & 12 & 0.4 & 17.5 & 3.8 & 5.4 \\
\hline & 120 & 15.1 & 5 & 86 & 218 & 22 & 12 & 0.6 & 63.0 & 3.6 & 5.6 \\
\hline & 20 & 0.7 & 3 & 48 & 23 & 15 & 12 & 5.2 & 3.1 & 5.9 & 5.6 \\
\hline & 120 & 22.6 & 2 & 152 & 37 & 15 & 12 & 33.2 & 10.7 & 5.2 & 4.7 \\
\hline & 40 & 2.5 & 2 & 18 & 13 & 15 & 12 & 0.7 & 0 & 4.4 & nd \\
\hline & 60 & 2.5 & 2 & 23 & 19 & 17 & 13 & 4.1 & 2.4 & 5.2 & 5.0 \\
\hline & 40 & 1.2 & 3 & 22 & 23 & 17 & 13 & 2 & 2.6 & 5.2 & 5.3 \\
\hline & 60 & 5.7 & 2 & 15 & 13 & 15 & 11 & 0 & 0 & nd & nd \\
\hline & 90 & 6.6 & 4 & 32 & 94 & 15 & 11 & 0.4 & 12.4 & 3.8 & 5.3 \\
\hline & 130 & 57.5 & 2 & 42 & 73 & 15 & 11 & 1.2 & 18.5 & 3.3 & 4.5 \\
\hline & 130 & 57.5 & 2 & 96 & 378 & 15 & 11 & 3.1 & 51.0 & 3.7 & 4.9 \\
\hline & 140 & 26.4 & 2 & 45 & 178 & 14 & 13 & 1.2 & 19.9 & 3.7 & 4.9 \\
\hline & 140 & 26.4 & 2 & 39 & 70 & 14 & 13 & 0.4 & 3.2 & 3.2 & 4.1 \\
\hline & 40 & 1.7 & 2 & 17 & 45 & 21 & 12 & 0 & 7.2 & nd & 5.6 \\
\hline & 25 & 0.7 & 2 & 15 & 18 & 21 & 12 & 0 & 1.3 & nd & 5.3 \\
\hline & 60 & 7.1 & 2 & 16 & 12 & 21 & 12 & 0 & 0 & nd & nd \\
\hline & 30 & 1.1 & 3 & 17 & 20 & 16 & 12 & 0 & 0.1 & nd & 4.0 \\
\hline
\end{tabular}




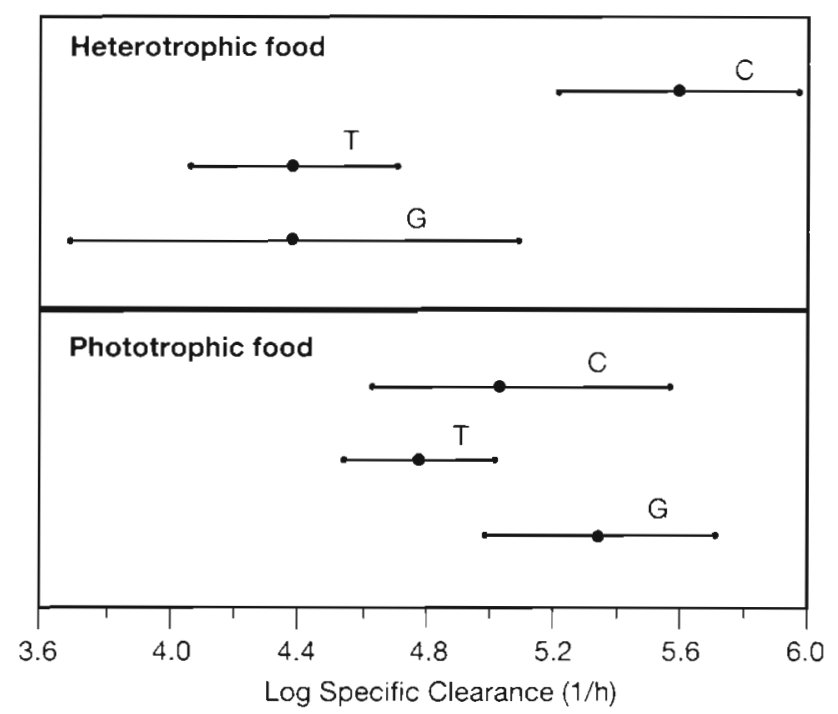

Fig. 1. Means and 95\% confidence intervals of log specific clearance rates (in fractions of $\mathrm{BV} \mathrm{h}^{-1}$ ) for heterotrophic and phototrophic food sources for the 3 grazer groups: ciliates (C), thecate dinoflagellates $(T)$, and gymnodinoid dinoflagellates $(G)$

gymnodinoids $\left(9.8 \times 10^{4}\right.$ to $\left.5.0 \times 10^{5} \mathrm{BV} \mathrm{h}^{-1}\right)$ and thecate dinoflagellates $\left(3.5 \times 10^{4}\right.$ to $\left.1.0 \times 10^{5} \mathrm{BV} \mathrm{h}^{-1}\right)$. But the $95 \% \mathrm{Cl}$ of size-specific herbivory by gymnodinoids and thecate dinoflagellates hardly overlapped at all.

Stenosemella and Helicostomella also had high selectivity indices, i.e. were mainly feeding on bacteria (Fig. 2a). However, other ciliates, such as Tiarina which were abundant during late stages of phytoplankton blooms during the upwelling season (Neuer 1992) and the non-loricate choreotrich, mostly utilized phototrophic food sources (selectivity index of $<0.3$ ). A strong selection for phototrophic food particles was displayed by gymnodinoid dinoflagellates, with 8 of 12 data points having selectivity values of 0 (Fig. 2b). Thecate dinoflagellates displayed a range of feeding selectivities. Most thecate dinoflagellates selected phytoplankton over heterotrophic food sources and about half (12 of the 26 data points) had selectivity values $<0.2$, i.e. were predominantly herbivorous (Fig. 2b). In none of the groups were the selectivity indices influenced by the size of the protists.

We investigated whether a size-relationship with specific clearance rate could be identified for the 3 protist groups. There was no such relationship for the ciliates, neither for feeding on heterotrophic nor on phototrophic food sources (Table 2). For thecate dinoflagellates only the size-dependency for feeding on bacteria was significantly different from zero (at $0.01<$ $p<0.05)$, but the slope was very small. The relationship was non-significant for feeding on phototrophic food sources (Table 2). However, for the gymnodinoids, there was a clear relationship with size for both food sources, with larger cells clearing fewer body volumes per unit time than smaller cells. The slopes of the regressions were both significantly different from 0 (at $p<0.01$; Fig. 3 ; Table 2), and $71 \%$ and $55 \%$ of the
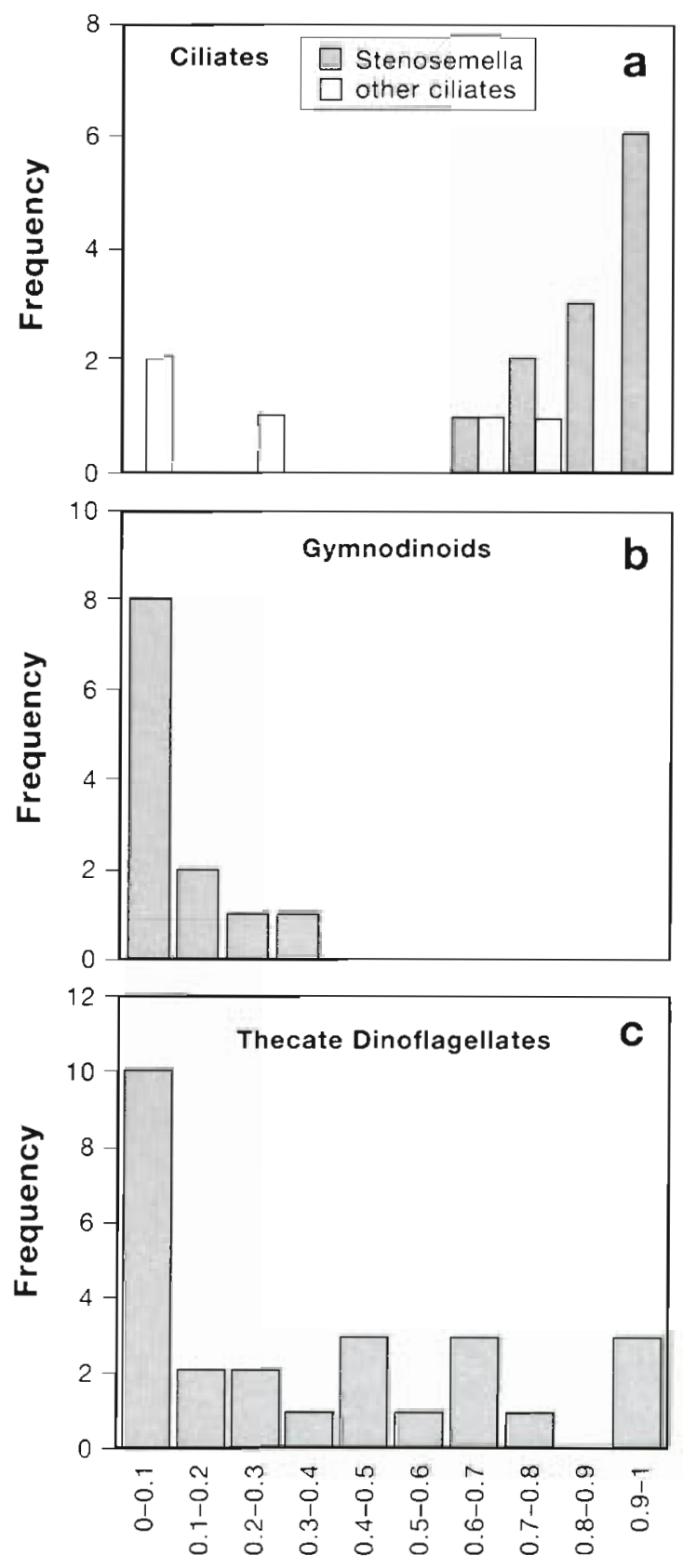

\section{Selectivity Index}

Fig. 2. Frequency distribution of selectivity indices (ratio of clearance on ${ }^{3} \mathrm{H}$-thymidine-labeled, heterotrophic food sources over the sum of clearance on ${ }^{3} \mathrm{H}$ - and ${ }^{14} \mathrm{C}$-bicarbonate-labelled, phototrophic food) for (a) ciliates, (b) gymnodinoids, and (c) thecate dinoflagellates. High selectivity indices $(>0.5)$ indicate a preference for heterotrophic food, lower values $\{<0.5\}$ a preference for phototrophic food sources. Each data point represents 1 vial containing 2 to 5 cells of a group (size, taxon) of organism 
Table 2. Summary of regression equations of $\log$ specific clearance rate (in fractions of $\mathrm{BV} \mathrm{h} \mathrm{h}^{-1}$ ) as a function of grazer biovolume $\left(\mathrm{\mu m}^{3}\right)$. The results are shown for both heterotrophic $\left({ }^{3} \mathrm{H}\right)$ and autotrophic $\left({ }^{14} \mathrm{C}\right)$ food sources. ns: slope of the straight line model is not significantly different from zero $(p>0.05)$

\begin{tabular}{|lcccccrr|}
\hline & Ciliates & \multicolumn{4}{c|}{ Dinoflagellates } \\
& & & \multicolumn{3}{c|}{ Thecate } & \multicolumn{2}{c|}{ Gymnodinoid } \\
& ${ }^{3} \mathrm{H}$ & ${ }^{14} \mathrm{C}$ & ${ }^{3} \mathrm{H}$ & ${ }^{14} \mathrm{C}$ & ${ }^{3} \mathrm{H}$ & ${ }^{14} \mathrm{C}$ \\
\hline Intercept & 5.59 & 5.05 & 4.71 & 4.90 & 5.77 & 6.22 \\
Slope $\left(\times 10^{-5}\right)$ & $\mathrm{ns}$ & $\mathrm{ns}$ & -0.28 & $\mathrm{~ns}$ & -2.69 & -1.51 \\
$\mathrm{R}^{2}$ & 0.00 & 0.00 & 0.26 & 0.06 & 0.71 & 0.55 \\
\hline
\end{tabular}

variability in $\log$ feeding rates on heterotrophic and phototrophic food could be explained by size. The intercept of the regression of specific clearance rates on size for phototrophic food sources was higher than that for heterotrophic food sources, supporting the selective utilization of phytoplankton found for this group.

\section{DISCUSSION}

Using the dual-label isotope method we could compare feeding performances of ciliates and dinoflagellates grazing on the natural food spectrum under close to in situ conditions. Accounting for the effects of cell size, we were able to compare size-specific clearance

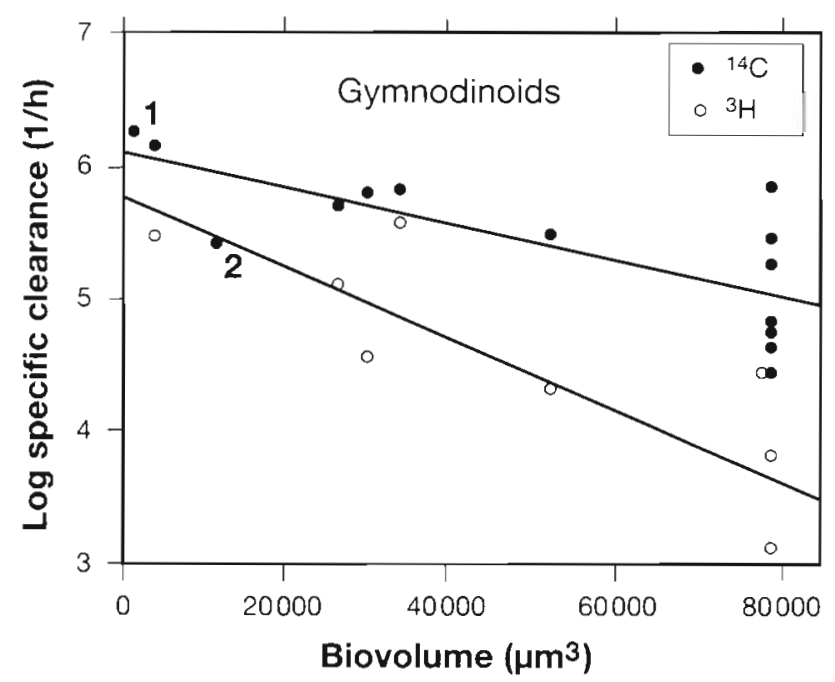

Fig. 3. Regression of log specific clearance rates (in fractions of $\left.\mathrm{BV} \mathrm{h}^{-1}\right)$ versus biovolume $\left(\mu^{3}\right)$ on phototrophic $(\bullet)$ and heterotrophic (0) food sources for gymnodinoid dinoflagellates. Marked data points: (1) maximum clearance rates obtained by Strom (1991) for a Gymnodinium sp. feeding on Isochrysis galbana; and (2) maximum clearance rate obtained by Hansen (1992) for Gyrodinium spirale feeding on Heterocapsa triquetrum rates. Bacterivory of both groups of heterotrophic dinoflagellates was found to be very similar. However, gymnodinoid dinoflagellates had higher mean rates of herbivory than thecate dinoflagellates. Ciliates and heterotrophic dinoflagellates differed in their relative utilization of phototrophic and heterotrophic prey. Ciliates had much higher clearance rates on heterotrophic food sources than the gymnodinoid and thecate dinoflagellates. Gymnodinoid dinoflagellates had the highest clearance rates, both absolute and specific, on phototrophic food sources compared to thecate dinoflagellates and ciliates. Small cells of gymnodinoid dinoflagellates tended to have higher specific clearance rates than larger cells. Such size-clearance rate relationships could not be identified for the ciliates.

Specific ciliate bacterivory was investigated for pelagic ciliates (mostly spirotrichs and scuticociliates with a biovolume of 450 to $1.8 \times 10^{4} \mu \mathrm{m}^{3}$ ) by Sherr \& Sherr (1987) using fluorescently labelled bacteria (FLB). The mean of the log specific clearance rates of their study (mean 5.05; 95\% CI: 4.82 to 5.27 ) is lower, but not significantly different (1-sample ANOVA, $\mathrm{p}<$ $0.05)$ from the mean of log specific clearance rates of this study (mean 5.59; $95 \%$ CI: 5.20 to 5.98 ; see also Fig. 1). In addition, log specific clearance rates obtained by the FLB method are also size independent (F-test: $p=0.11, R^{2}=0$ ). The agreement between the data of these methodologically different approaches shows that the high consumption of bacteria found by Sherr \& Sherr (1987) is also possible for larger ciliates.

We also analyzed size-specific clearance rates on phytoplankton cells obtained in different culture studies for several species of choreotrich ciliates (data from Verity 1985, 1991, and Jonsson 1986; biovolume

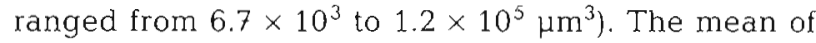
the maximum log specific clearance rates was $5.1 \mathrm{~h}^{-1}$ (95\% CI: 4.86 to $5.35 \mathrm{~h}^{-1}$ ) which was not different from the mean of $\log$ specific clearance rates obtained in this study $(5.03 ; 95 \% \mathrm{CI}: 4.63$ to 5.56 ; Fig. 1). There was also no significant relationship of log specific clearance rates with size ( $F$-test: $\mathrm{p}=0.72, \mathrm{R}^{2}=0$ ).

The independence of specific clearance rates with size found for planktonic ciliates contradicts earlier findings by Fenchel (1980) who found a significant size-relationship for benthic ciliates (size range 600 to $5 \times 10^{4} \mu^{3}$ ) feeding on bacteria-sized latex beads. The negative slope of his data (as a double logarithmic presentation) is close to 0.25 , which is comparable to the general allometric relationships found for growth and specific metabolic rates (see Moloney \& Field 1989 for a review). The apparently contradictory constancy of specific clearance rates found for planktonic ciliates (in this study, Sherr \& Sherr 1987, and data compiled from Verity 1985, 1991, and Jonsson 1986) could be caused by several factors. For example, interspecific or inter- 
generic variability in clearance rates and food selectivity (see Fig. 1) may obscure a size relationship. Furthermore, Fenchel (1980) found that in suspension feeders such as ciliates, clearance rates are nearly proportional to the optimal prey size range. Thus, if ciliates are offered a natural food spectrum, larger ciliates will ingest larger prey and thus exhibit larger clearance rates which would compensate for a negative relationship of specific clearance rates with size. The question of a size dependency of clearance rates in the field deserves further attention since it determines how prey populations are affected by the size distribution of the grazers.

Strom \& Buskey (1993) found log specific clearance rates of $4.62 \mathrm{~h}^{-1}$ in laboratory experiments for the thecate dinoflagellate Oblea rotundata (biovolume $4849 \mathrm{\mu m}^{3}$ ) feeding on its preferred food, the diatom Ditylum brightwellii. This rate agrees very well with the mean log specific clearance rate for herbivory found in our study $\left(4.78 \mathrm{~h}^{-1}\right.$; Fig. 1). Lessard \& Swift (1985) show clearance rates for thecate dinoflagellates similar to our data when applying the dual-label isotope method in North Atlantic waters, with a median of 1.9 and $3.3 \mu l \mathrm{~h}^{-1}$ for feeding on heterotrophic and phototrophic food sources, respectively. They also found that many thecate dinoflagellates preferred phototrophic cells as food, but many cells exhibited less selective feeding behaviour.

Many thecate dinoflagellates feed with a pallium, a pseudopod with which they enclose diatoms or even chains of diatoms. But some thecate dinoflagellates have also been observed to capture small detrital particles with attached bacteria (Jacobson \& Anderson 1986; see Schnepf \& Elbrächter 1992 for a review). Thus, it is not surprising to find conditions under which thecate dinoflagellates show unselective feeding

Gymnodinoid grazing on phytoplankton cells has been previously investigated in laboratory and microcosm studies (Bjørnsen \& Kuparinen 1991, Strom 1991, Hansen 1992). We included the maximum specific clearance rates obtained in the studies by Strom (1991) and Hansen (1992) in Fig. 3. Including these data points in our regression of size-specific clearance rates on phototrophic particles, we find a very good agreement, with the regression parameters changing only slightly (intercept 6.1, slope $-1.34 \times 10^{-5}, \mathrm{R}^{2}=0.56$ ). The experimental result obtained by Bjørnsen \& Kuparinen (1991) (specific clearance rate of only $0.12 \times$ $10^{6} \mathrm{~h}^{-1}$ at a biovolume of $1000 \mu \mathrm{m}^{3}$ ) was not considered because of the large difference in temperature $\left(1{ }^{\circ} \mathrm{C}\right.$, versus 10 to $15^{\circ} \mathrm{C}$ in Strom 1991, Hansen 1992 and the present study). Because of the strong size-clearance rate relationship found for gymnodinoid dinoflagellates, their importance as herbivores will depend on

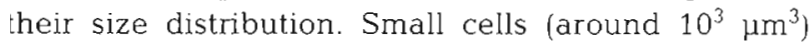

have log specific clearance rates an order of magnitude higher $\left(6.2 \mathrm{~h}^{-1}\right)$ than those of ciliates $\left(5.03 \mathrm{~h}^{-1}\right)$ or thecate dinoflagellates $\left(4.78 \mathrm{~h}^{-1}\right)$ of the same size. But this difference decreases gradually as size-specific rates of gymnodinoids decrease with increasing cell size. At a cell size of $10^{5}{\mu m^{3}}^{3}, \log$ specific clearance rates of all groups become approximately equal $\left(4.7 \mathrm{~h}^{-1}\right)$.

Our results indicate that gymnodinoids feed more specifically on phototrophic than on heterotrophic food (Fig. 2a). We and other researchers observed gymnodinoids with ingested diatoms and phototrophic dinoflagellates in their food vacuoles (see also Hansen 1991 for a review). Gymnodinoid dinoflagellates often cooccur in the field with blooms of large diatoms or chains of diatoms (see Hansen 1991, Neuer 1992). Gymnodinoids also were found to feed on nanoflagellates and Synechococcus (Kofoid \& Swezy 1921, Strom 1991, Schnepf \& Elbrächter 1992). But so far, rates of bacterivory have not been reported. Smaller forms are probably routinely included in the functional group of heterotrophic nanoflagellates which have been shown to be bacterivorous (e.g. Sherr \& Sherr 1991). Because of the strong relationship of specific clearance rate with size found in this study, the size frequency distribution of gymnodinoids in the field will have a large influence on the importance of gymnodinoids as bacterivores. Based on the size-clearance rate relationships found here (Table 2), smaller forms $\left(<10000 \mu \mathrm{m}^{3}\right)$ have log specific clearance rates on bacteria equal to or larger than those of ciliates. Larger-sized cells $\left(>50000 \mu \mathrm{m}^{3}\right)$, however, have log specific clearance rates on bacteria smaller than those of ciliates and thecate dinoflagellates of the same size.

The comparison of size-specific feeding rates of ciliates and dinoflagellates investigated in our study has shown that mean specific rates of herbivory are similar between the groups, but that ciliates display higher specific rates of bacterivory. An interesting difference exists between gymnodinoid and thecate dinoflagellates: while rates of bacterivory are similar, herbivory is much higher in gymnodinoid forms. A strong relationship of size with specific clearance rates found for the gymnodinoid dinoflagellates indicates that in assessing the impact of ciliates and dinoflagellates on their prey, size distributions of the grazers in the field need to be considered.

Acknowledgements. We thank L. Fessenden and M.-L. Dickson for help at sea and the Captains of the RV 'Saccajawea for their cooperation. P. A. Wheeler is gratefully acknowledged for support and laboratory space at the Hatfield Marine Science Center, Newport, Oregon. G. Taghon and R. Greene provided and helped with the Image Analysis system Thoughtful suggestions by F. Garcia-Pichel, E. and B. Sherr $S$. Gregory and $M$. Abbott and anonymous reviewers improved the manuscript. This work was supported by NSF grant OCE-8620174 to T.C., J. Moum and P. Wheeler. 


\section{LITERATURE CITED}

Banse K (1982) Cell volumes, maximal growth rates of unicellular algae and ciliates, and the role of ciliates in the marine pelagial. Limnol Oceanogr 27:1059-1071

Bjornsen PK, Kuparinen J (1991) Growth and herbivory by heterotrophic dinoflagellates in the Southern Ocean, studied by microcosm experiments. Mar Biol 109:397-405

Corliss JO (1979) The ciliated protozoa. Pergamon Press, Oxford

Daro MH (1978) A simplified ${ }^{14} \mathrm{C}$ method for grazing measurements on natural plankton populations. Helgoländer wiss Meeresunters 31:241-248

Dodge JD (1982) Marine dinoflagellates of the British Isles. Her Majesty's Stationery Office, London

Edler L (ed) (1979) Recommendations on methods for marine biological studies in the Batlic Sea. Phytoplankton and chlorophyll. The Baltic Marine Biologists, Malmö

Fenchel T (1980) Suspension feeding in ciliated protozoa feeding rates and their ecological significance. Microb Ecol 6:13-25

Fenchel T (1986) Protozoan filter feeding. Prog Protistol 1: 65-113

Frost BW (1972) Effects of size and concentration of food particles on the feeding behavior of the marine planktonic copepod Calanus pacificus. Limnol Oceanogr 17:805-815

Gaines G, Taylor FJR (1984) Extracellular digestion in marine dinoflagellates. J Plankton Res 6:1057-1061

Hansen PJ (1991) Quantitative importance and trophic role of heterotrophic dinoflagellates in a coastal pelagial foodweb. Mar Ecol Prog Ser 73:253-261.

Hansen PJ (1992) Prey size selection, feeding rates and growth dynamics of heterotrophic dinoflagellates with special emphasis on Gyrodinium spirale. Mar Biol 114: $327-334$

Heinbokel JF (1978) Studies on the functional role of tintinnids in the Southern California Bight. II. Grazing rates of field populations. Mar Biol 47:191-197

Jacobson DM, Anderson DM (1986) Thecate heterotrophic dinoflagellates: feeding behavior and mechanisms. J Phycol 22:249-258

Jeong HJ, Latz MI (1994) Growth and grazing rates of the heterotrophic dinoflagellate Protoperidinium spp. on red tide dinoflagellates. Mar Ecol Prog Ser 106:173-185

Jonsson PR (1986) Particle size selection, feeding rates and growth dynamics of marine planktonic oligotrichous cilaites (Ciliophora: Oligotrichina). Mar Ecol Prog Ser 33: 265-277

Kofoid CA, Swezy O (1921). The free-living unarmored Dinoflagellata. Mem Univ Cal 5:1-538

Landry MR, Hassett RP (1982) Estimating the grazing impact of marine micro-zooplankton. Mar Biol 67:283-288

Lessard EJ (1991) The trophic role of heterotrophic dino-

This article was submitted to the editor flagellates in diverse marine environments. Mar microb Food Webs 5:49-58

Lessard EJ, Swift E (1985) Species-specific grazing rates of heterotrophic dinoflagellates in oceanic waters, measured with a dual-label isotope technique. Mar Biol 87:289-296

Lessard EJ, Swift E (1986) Dinoflagellates from the North Atlantic classified as phototrophic or heterotrophic by epifluorescence microscopy. J Plankton Res 8:1209-1215

Moloney CL, Field JG (1989) General allometric equations for rates of nutrient uptake, ingestion, and respiration in plankton organisms. Limnol Oceanogr 34:1290-1299

Nakamura Y, Yamazaki Y, Hiromi J (1992) Growth and grazing of a heterotrophic dinoflagellate, Gyrodinium dominans, feeding on a red tide flagellate, Chattonella antiqua. Mar Ecol Prog Ser 82:275-279

Neuer S (1992) Role of protist grazing in the Oregon Upwelling System. PhD thesis, Oregon State University, Corvallis

Neuer S, Cowles TJ (1994) Protist herbivory in the Oregon upwelling system. Mar Ecol Prog Ser 113:147-162

Rassoulzadegan F (1982) Dependence of grazing rate, gross growth efficiency and food size range on temperature in a pelagic oligotrich ciliate Lohmaniella spiralis Leeg., fed on naturally occurring particulate matter. Annls Inst océanogr, Paris 58:177-184

Schnepf E, Elbrächter $M$ (1992) Nutritional strategies in dinoflagellates. A review with emphasis on cell biological aspects. Eur J Protistol 28:3-24

Sherr BF, Sherr EB (1991) Proportional distribution of total numbers, biovolume, and bacterivory among size classes of $2-20 \mu \mathrm{m}$ nonpigmented marine flagellates. Mar microb Food Webs 5:227-237

Sherr BF, Sherr EB, Rassoulzadegan F (1988) Rates of digestion of bacteria by marine phagotrophic protozoa: temperature dependence. Appl environ Microbiol 54:1091-1095

Sherr EB, Sherr BF (1987) High consumption of bacteria by pelagic ciliates. Nature 325:710-711

Sokal RR, Rohlf FJ (1981) Biometry. WH Freeman and Company, San Francisco

Stoecker DK, Capuzzo JM (1990) Predation on protozoa: its importance to zooplankton. J Plankton Res 12:891-908

Strom S (1991) Grazing and growth rates of the herbivorous dinoflagellate Gymnodinium sp. from the subarctic Pacific Ocean. Mar Ecol Prog Ser 78:103-113

Strom SL, Buskey EJ (1993) Feeding, growth, and behavior of the thecate heterotrophic dinoflagellate Oblea rotundata. Limnol Oceanogr 38:965-977

Verity PG (1985) Grazing, respiration, excretion, and growth rates of tintinnids. Limnol Oceanogr 30:1268-1282

Verity PG (1991) Measurement and simulation of prey uptake by marine planktonic ciliates fed plastidic and aplastidic nanoplankton. Limnol Oceanogr 36:729-750

Wailes GH (1939) Canadian Pacific fauna. 1. Protozoa. 1f. Ciliata. The University of Toronto Press, Toronto, p 1-37

Manuscript first received: December 15, 1994

Revised version accepted: April 3, 1995 